\title{
Indole monoterpene alkaloids from Chimarrhis turbinata DC Prodr.: a contribution to the chemotaxonomic studies of the Rubiaceae family
}

\author{
Carmen L. Cardoso, ${ }^{1}$ Dulce Helena S. Silva, ${ }^{2}$ Maria Cláudia M. Young, ${ }^{3}$ \\ Ian Castro-Gamboa, ${ }^{2}$ Vanderlan da Silva Bolzani*,2 \\ ${ }^{1}$ Departamento de Química, Faculdade de Filosofia, Ciências e Letras de Ribeirão Preto, \\ Universidade de São Paulo, 14040-901 Ribeirão Preto-SP, Brazil, \\ ${ }^{2}$ Núcleo de Bioensaios, Biossintese e Ecofisiologia de Produtos Naturais (NuBBE), Instituto de Química, \\ Universidade Estadual Paulista, CP 355, 14801-970 Araraquara-SP, Brazil, \\ ${ }^{3}$ Seção de Fisiologia e Bioquímica de Plantas, Instituto de Botânica, Caixa Postal 4005, 04301-012
}

São Paulo-SP, Brazil

\begin{abstract}
RESUMO: "Alcalóides indólicos monoterpênicos de Chimarrhis turbinata DC. Prodr.: uma contribuição para os estudos de quimiotaxonomia da família Rubiaceae". A utilização de parâmetros apenas morfológicos para posicionar taxonomicamente diversas espécies em subfamílias e tribos na família Rubiaceae é bastante problemática devido à falta de informações sobre a distribuição geográfica e de características morfoanatômicas nos níveis hierárquicos mais baixos, como por exemplo, o gênero Chimarrhis. O perfil micromolecular de diferentes espécies pode auxiliar na delimitação de tribos indicando tendências filogenéticas mais completas entre as tribos das sub-famílias, já que os metabólitos secundários são expressões de adaptação, regulação e evolução de um determinado táxon. Nesse contexto, os alcalóides indólicos monoterpênicos isolados de Chimarrhis turbinata foram bastante úteis para embasar a classificação taxonômica feita por Robbrecht, em que posiciona Chimarrhis como um gênero da tribo Condamineae e subfamília Cinchonoideae.
\end{abstract}

Unitermos: Chimarrhis turbinata, Rubiaceae, alcalóides indólicos monoterpenos, quimiotaxonomia.

\begin{abstract}
The morphological parameters used to establish close connections among species taxonomically different into the Rubiaceae family is complex, mainly due to the lack of information on habitat and morphoanatomical characters in the lower hierarchic groups, for example, Chimarrhis genus. The micromolecular profile of delimited species into determined taxa can be useful to establish the boundaries among close taxonomic groups, and to indicate evolutionary phylogenetic trends into the taxa. Several indole alkaloids isolated from C. turbinata showed to be a valuable tool to support the taxonomic classification performed by Robbrecht, who established the most recent taxonomy for Rubiaceae, based on morphological characters, and concluded that Chimarrhis belong to Condamineae, and subfamily Cinchonoideae.
\end{abstract}

Keywords: Chimarrhis turbinata, Rubiaceae, indole monotepene alkaloids, chemotaxonomy.

\section{INTRODUCTION}

Chimarrhis turbinata is a tree that grows from Caribbean to tropical South America, and occurs predominantly in the Amazonian region (Boom and Campos, 1991). It is popularly named "pau de remo", due to its light and yellow hardwood. It is also a resistant wood to insects and other predator attacks, and due to this characteristic it is used for sawmill, mainly in the craft and manufacture, of pawls (Delprete, 1996). In our previous study on leaves of Chimarrhis turbinata we have isolated strictosidine (1), a monoterpene indole alkaloid glycoside, well-known as the precursor of the monoterpene indole alkaloids and it was first isolated from Rhazya stricta (Smith, 1968). In addition, several corinantheane derivatives: $5 \alpha$-carboxystrictosidine (2), isovallesiachotamine (3), vallesiachotamine (4) (Arbain et. Al., 1992; Bolzani et al., 2001), turbinatine (5) and 3,4-dehydro-strictosidine (6) (Cardoso et al., 2003; Bolzani et al., 2001, Cardoso et al., 2004) were also isolated. Turbinatine (5) was considered an important intermediate key in the biosynthesis of the corinanthean indole alkaloids (Cardoso et al., 2003). Aiming to determine the chemical profile from this plant species for further chemosystematics evaluation of this biogenetic group in Rubiaceae, we performed 
<smiles>C=CC1[C@H](CC2NCCc3c2[nH]c2ccccc32)OC=C(C(=O)OC)[C@H]1OCC</smiles><smiles>C=CC1C(/C(=C/O)C(=O)OC)C[C@@H]2c3[nH]c4ccccc4c3CCN2C1OC</smiles>

5<smiles></smiles>

8<smiles>C=CC1C(C[C@@H]2NC(C(=O)O)Cc3c2[nH]c2ccccc32)C(C(=O)O)=CO[C@H]1OCC</smiles>

2<smiles>C=CC1C(CC2=NCCc3c2[nH]c2ccccc32)C(C(=O)OC)=CO[C@@H]1OC</smiles>

6<smiles>C=CC1C(OC)OC=C(C(=O)OC)C1Cc1nc(C(=O)O)cc2c1[nH]c1ccc(O)cc12</smiles>

9<smiles>Cc1nc(C(=O)O)cc2c1[nH]c1ccccc12</smiles><smiles>[R]C([R2])=C(C(=O)OC)[C@H]1C[C@@H]2c3[nH]c4ccccc4c3CCN2C=C1C(=O)O</smiles>

$\begin{array}{lll} & \mathrm{R}_{1} & \mathrm{R}_{2} \\ 3 & \mathrm{CH}_{3} & \mathrm{H} \\ 4 & \mathrm{H} & \mathrm{CH}_{3}\end{array}$<smiles>C=CC1C(CC2=NCCc3c2[nH]c2ccccc32)C(C(=O)O)=CO[C@@H]1OC</smiles>

7<smiles>C=CC1C(OC)OC=C(C(=O)O)C1Cc1nc(C(=O)O)cc2c1[nH]c1ccccc12</smiles>

10

11

Figure 1. Indole terpene alkaloids profile from Chimarrhis turbinata.

the chemical studies of the EtOH extract obtained from barks of this species, which resulted in the isolation of the indole glucoalkaloids identified as 3,4-dehydrostrictosidine acid (7) (Cardoso et al., 2004), strictosidine acid (8), the $\beta$-carboline alkaloids: cordifoline (9), deoxycordifoline (10), and harman-3-carboxylic acid (11) previously isolated from Adina species (Brown and Warambwa, 1978; Blackstock et al., 1972), along with strictosidine (1), $5 \alpha$-carboxistrictosidine (2) and turbinatine (5) already isolated from the leaves of $C$. turbinata (Cardoso et al., 2003) Figure 1.

Concerning the distribution of the main secondary metabolites in Rubiaceae (Robbrecht, 1988), indole alkaloids were the chemotaxonomic markers more intensely studied so far, aiming the establishment of phyllogenetic correlations between secondary metabolites and taxonomic data. Our chemical studies revealed several interesting correlations among tribes and subfamilies of Rubiaceae due to their structural variability and restrict distribution (Bolzani et al., 2001). In Rubiaceae, the occurrence and distribution of iridoids, indole alkaloids and anthraquinones has provided valuable chemosystematic clues (Young et al., 1996).

\section{MATERIAL AND METHODS}

\section{Plant material}

Chimarrhis turbianta (DC) Prodr. (Rubiaceae) was collected in the Reserva do Viro, Belém, PA, Brazil in February 2000 and identified by Dr. Marina Thereza V. de A. Campos. An air-dried voucher specimen was deposited in the Herbarium of the Botanic Garden, São Paulo and catalogued as Lopes-51. 


\section{Extraction and isolation}

The bark (300 g) was extracted with EtOH and dissolved in $n$-BuOH: $\mathrm{H}_{2} \mathrm{O}$, followed by partition with $\mathrm{CH}_{2} \mathrm{Cl}_{2}$ : hexane (1:1), $\mathrm{CHCl}_{3}$ and EtOAc. The remaining aqueous layer after concentration resulted in a fraction WT $(10 \mathrm{~g})$. The $n$ - $\mathrm{BuOH}: \mathrm{H}_{2} \mathrm{O}$ solution was concentrated and dissolved in $\mathrm{MeOH}: \mathrm{H}_{2} \mathrm{O}$ followed by partition with $\mathrm{CH}_{2} \mathrm{Cl}_{2}$ :hexane $(1: 1), \mathrm{CHCl}_{3}$ and EtOAc. The $\mathrm{MeOH}: \mathrm{H}_{2} \mathrm{O}$ layer after concentration, resulted in fraction WM (12 g). Fraction WT was chromatographed by VLC (vacuum liquid chromatography) on reverse phase silicagel, using $\mathrm{H}_{2} \mathrm{O}, \mathrm{MeOH}: \mathrm{H}_{2} \mathrm{O}$ in a gradient $(25-100 \%)$, acetone $(100 \%)$ and $\mathrm{CH}_{2} \mathrm{Cl}_{2}$ yielding 11 fractions (A-K). Fraction A was purified by HPLC (Phenomenex-Luna $\mathrm{C} 18,25.0 \mathrm{~cm}$ x $21.20 \mathrm{~mm}$ x $5 \mu \mathrm{m}$ column; $\mathrm{MeCN}: \mathrm{H}_{2} \mathrm{O}$ + HOAc $(0.05 \%) 15: 85 \lambda=237 \mathrm{~nm}$, flow rate 12 $\mathrm{mL} \cdot \mathrm{min}^{-1}$ ) affording 10 fractions. From these A-5, A-7 and A-9 were identified as strictosidine acid $(\mathbf{8})(15 \mathrm{mg})$, strictosidine (1) $(6 \mathrm{mg})$ and $5 \alpha$-carboxystrictosidine (2) $(25 \mathrm{mg})$ respectively. Fractions A-3, A-4 and A-10 were purified by HPLC using the following conditions (Phenomenex-Luna C18, $25.0 \mathrm{~cm} \times 21.20 \mathrm{~mm} \times 5 \mu \mathrm{m}$ column; $\mathrm{MeCN}: \mathrm{H}_{2} \mathrm{O}+\mathrm{HOAc}(0.05 \%)$ 15:85 $\lambda=237 \mathrm{~nm}$, flow rate $7.5 \mathrm{~mL} \cdot \mathrm{min}^{-1}$ ); (Phenomenex-Luna C18, 25.0 $\mathrm{cm} \times 21.20 \mathrm{~mm} \times 5 \mu \mathrm{m}$ column; $\mathrm{MeCN}: \mathrm{H}_{2} \mathrm{O}+\mathrm{HOAc}$ (0.05\%) $13: 87, \lambda=237 \mathrm{~nm}$, flow rate $12 \mathrm{~mL} \cdot \mathrm{min}^{-1}$ ); (Phenomenex-Luna C18, $25.0 \mathrm{~cm} \times 21.20 \mathrm{~mm}$ x $5 \mu \mathrm{m}$ column; $\mathrm{ACN}: \mathrm{H}_{2} \mathrm{O}+\mathrm{HOAc}(0.05 \%) 2: 8, \lambda=237 \mathrm{~nm}$, flow rate $\left.12 \mathrm{~mL} \cdot \mathrm{min}^{-1}\right)$, respectively. From fraction A-3 the iridoid sweroside (19) $(2.5 \mathrm{mg})$ only representative of this class of secondary metabolite, isolated from this species.

From fractions A-4 and A-10 we isolated: harman-3-carboxylic acid (11) (20 mg), cordifoline (9) $(16.2 \mathrm{mg})$, turbinatine $(5)(14 \mathrm{mg})$ and deoxycordifoline

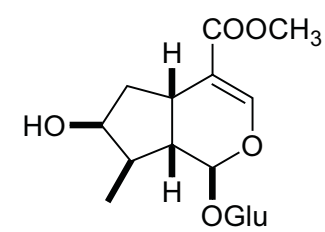

12

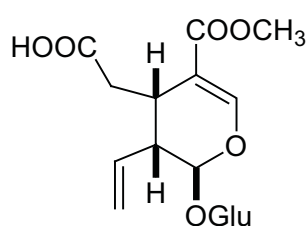

13<smiles>COC(=O)C1C=COC(O)C2(C)CC(=O)O[C@H](C)[C@]12C(C)=O</smiles>

14<smiles>C1CCC1</smiles><smiles>COC(=O)C1=COC(O)C(C)(O)C1(CC(=O)O)C(C)OC(C)=O</smiles>

15<smiles>COC(=O)C[C@H]1C(C(C)=O)=COC(O)[C@H]1C(C)OC(C)=O</smiles>

16<smiles>CC=C(C)C(=O)OC(C)[C@H]1C(OC)OC=C(C(C)=O)[C@H]1CC(=O)O</smiles>

17

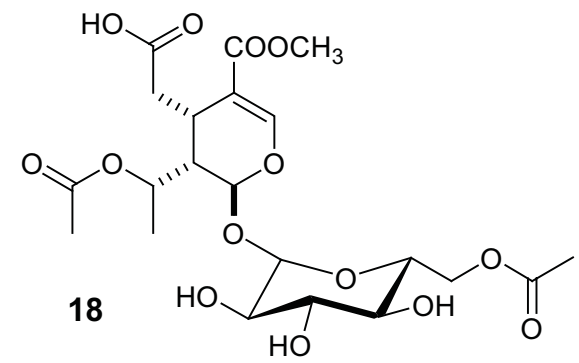<smiles>C=C[C@@H]1C(OC)OC=C2C(=O)OCCC21</smiles>

Figure 2. Seco-iridoids isolated from Calycophylum spruceanum.

(10) $(20 \mathrm{mg}$ ) previously isolated from leaves of $C$. turbinata (Cardoso et al., 2003).

Fraction WM (12 g) was purified by HPLC (Phenomenex-Luna C-18, $25.0 \mathrm{~cm}$ x $21.20 \mathrm{~mm}$ x $5 \mu \mathrm{m}, \mathrm{MeCN}: \mathrm{H}_{2} \mathrm{O}+\mathrm{HOAc}(0.05 \%) 15: 85 \lambda=254$ $\mathrm{nm}$, flow rate $12 \mathrm{~mL} \cdot \mathrm{min}^{-1}$ ), affording 10 fractions. After recrystallization, fraction W-4 was identified as harman-3-carboxylic acid (11) (17 mg). Fractions W-5 and W-6 were identified as cordifoline (9) $(7 \mathrm{mg})$, and 3,4-dehydro-strictosidine acid (7) $(5 \mathrm{mg})$, respectively (Cardoso et al., 2004). Fractions W-9 and W-10 were deoxycordifoline (10) (148 mg), respectively.

\section{RESULTS AND DISCUSSION}

According to the new taxonomic classification currently adopted for the Rubiaceae family, $C$. turbinata is placed into the subfamily Cinchonoideae, which had its classification based on a series of morphological parameters such as placentation, fruit and seed morphology and anatomy (Robbrecht, 1988). The chemical profile for each subfamily, as expressed by occurrence of the major categories of secondary al., 1996). However, according to our studies, and classification adopted by Robbrechet (Robbrecht, 1988), the position of many species into the several Rubiaceae tres, including Condamineae, remain problematic, many taxa. So far, secondary metabolites profile can contribute to the taxonomic position of some tribes, which remain with a morphological controversy. Indole terpene alkaloids isolated in this study corroborated the 
evolutionary taxonomic distribution made by Robbrecht, who placed C. turbinata in the Condamineae contrary to that proposed by Verdcourt, who placed this genus into the Rondeletieae (Verdcourt, 1958).

The corynantheane indole alkaloids isolated from $C$. turbinata revealed its great affinity with Cinchonoideae, which was proved by the occurrence of several alkaloids with corynanthean skeleton. The morphoanatomical evaluation performed by Delprete on Chimarrhis, Calicophyllum and Bathysa indicated some parallelism among these genera, placing Chimarrhis at the basal clad position (Delprete, 1996). However, the chemical profile of some species from these genera evidences the occurrence of different biosynthetic pathways. For example, triterpenes (Benevides et. al., 2001) and paeonol (Weeks et al., 1977) have been isolated from Bathysa meridionalis. Triterpenes are frequent in several species of Rubiaceae, and so far are not considered taxonomic markers. Calycoplyllum spruceanum accumulates seco-iridoids (12-18) as major metabolites (Zuleta et. al., 2003) (Figure 2), whereas Chimarrhis turbinata indole-alkaloids (Cardoso et al., 2003, Cardoso et al., 2004) (Figure 1). The chemotaxonomical correlations found in this taxon, point out seco-iridoids as the precursor of all carboxy- or seco-iridoids, (ex. Ixoroideae subfamily). However, in Cinchonoideae, seco-iridoids are involved in the biosynthesis of indole terpene alkaloids and thus establishing two distinct chemotaxonomic branches (Nagakura et al., 1979).

Evaluation of the chemical data through Robbrecht parameters evidenced a good correlation between the biosynthetic pathways and morphological features for Rubiaceae subfamilies (Bolzani et al., 2001). In subfamily Cinchonoideae, indole alkaloids predominates, while iridoids are exclusively found in Ixoroideae (Young et al., 1996). Nevertheless, the micromolecular profile and the presence of indole alkaloid both in leaves and barks of C. turbinata can be helpful to the taxonomy and phylogeny and corroborating Chimarrhis classification according to Delprete as a species from the Cinchonoideae subfamily. However, the Chimarrhis's position into the Condamineae is still difficult to support and a deep evaluation, and additional chemotaxonomic studies will be necessary in order to establish the boundaries along this genus.

\section{ACKNOWLEDGMENTS}

This work was supported by the State of São Paulo Research Foundation (FAPESP) within the BIOTA/FAPESP (Biodiversity Virtual Institute Program) (www.biota.org.br), CNPq (Conselho Nacional de Desenvolvimento Científico e Tecnológico, Brazil). C. L. C. thanks FAPESP for a scholarship, and M. C. M. Y., M. F, and V. S. B. thank CNPq for research fellowships.

\section{REFERENCES}

Arbain D, Byrne LT, Putra MM, Sargent MV, Syarif M 1992. A new glucoalkaloid from Uncaria glabrata. J Chem Soc Perkin Trans 1: 665-667.

Benevides PJC 2001. Estudo fitoquímico de três espécies vegetais ocorrentes na Mata Atlântica e Amazônia guiado por dois bioensaios. 2001. 250 f. Tese de Doutorado em Química Orgânica - Universidade de São Paulo, São Paulo, 2001.

Blackstock WP, Brown RT, Chapple CL, Fraser SB 1972. Adina alkaloids. Deoxycordifoline, $3 \alpha, 5 \alpha-$ and $3 \beta, 5 \alpha$-tetrahydrodeoxycordifoline lactam. Chem Commun 18: 1006-1007.

Bolzani VS, Young MCM, Furlan M, Cavalheiro AJ, Araújo AR, Silva DHS, Lopes MN 2001. Secondary metabolites from Brazilian Rubiaceae plant species: Chemotaxonomical and biological significance. Recent Res Devel Phytochem 5: 19-31.

Boom BM, Campos MTVA 1991. A preliminary account of the Rubiaceae of a central Amazonian terra firme forest. Bol Mus Para Emilio Goeldi, ser Bot 7: 223-247.

Brown RT, Warambwa BFM 1978. Adina alkaloids: Isolation of desoxycordifoline. Phytochemistry 17: 1686-1687.

Cardoso CL, Silva DHS, Gamboa CI, Young MCM, BolzaniVS 2004. Indole glucoalkaloids from Chimarhis turbinata and their evaluation as antioxidant agents and acetylcholinesterase inhibitors. $J$ Nat Prod 67: 1882-1885.

Cardoso CL, Silva DHS, Tomazela DM, Young MCM, Eberlin MN, Verli H, Bolzani VS 2003. Turbinatine a potential key intermediate in the biosynthesis of corynanthean-type indole alkaloids $J$ Nat Prod 66: 1017-1021.

Delprete GP 1996. Notes on Calycophyllous Rubiaceae. 1. Morphological comparisons of the genera Chimarrhis, Bathysa, and Calycophyllum, with new combinations and a new species, Chimarrhis gentryana. Brittonia 48: 35-44.

Nagakura N, Rüffer M, Zenk MH 1979. Biosynthesis of monoterpenoid indole alkaloids from strictosidine. $J$ Chem Soc Perkin I 9: 2308-2311.

Robbrecht E 1988. Tropical woody Rubiaceae. Opera Bot Belg 1: 1-271.

Sanchez LWE, Brown Jr KS 1972. New beta carboline alkaloids from Aspidosperma-exalatum monachino. An Acad Bras Cienc 43: 603-605.

Smith GN 1968. Strictosidine - a key intermediate in biogenesis of indole alkaloids. Chem Comm 15: 912-914.

Verdcourt B 1958. Remarks on classification of Rubiaceae. Bull Jard Bot État Brux 28: 209-290.

Weeks RA, Dobberstein RH, Farnsworth NR 1977. Isolation of paeonol from Bathysa meridionalis. Lloydia 40: 515-518.

Young MCM, Braga MR, Dietrich SMC, Bolzani VS, Trevisan LMV, Gottlieb OR 1996. Chemosystematic markers of Rubiaceae. Opera Bot Belg 7: 205-212.

Zuleta LMC, Cavalheiro AJ, Silva DHS, Furlan M, Young MCY, Albuquerque S, Castro-Gamboa I, Bolzani VS. 2003. seco-Iridoids from Calycophyllum spruceanum (Rubiaceae) Phytochemistry 64: 549-553. 